\title{
A separation of the direct toxic effects of dietary raw egg white powder from its action in producing biotin deficiency
}

\author{
By J. M. PETERS \\ Department of Pharmacology, Queen's University, Kingston, Ontario, Canada
}

(Received 9 December 1966-Accepted 7 August 1967)

\begin{abstract}
1. Young adult female albino rats were given $20,40,60,80$, and $100 \%$ raw egg white powder in their diet; controls were fed on laboratory chow. Daily clinical measurements were made for 2 weeks. 'The rats were then killed, and the weights and water contents of various organs were determined.

2. The experiment was repeated with groups of young male albino rats fed for 2 and 4 weeks.

3. Toxic signs caused by increasing intake of dried raw egg white powder were: decreased food intake, weight loss, soft stool, diarrhoea, glycosuria and death. Water intake and urine output rose with increasing raw egg white powder in the diet. In all groups the urine was alkaline and the urinary output of protein increased. At autopsy there was a decrease in the absolute weight and in the water content of most body organs with increasing amounts of raw egg white powder in the diet.

4. The toxicity syndrome was not prevented by a biotin supplement, but was largely prevented by heat denaturation of the egg white powder; $80 \%$ of denatured egg white was well tolerated, as was $80 \%$ of casein in the diet.

5. The syndrome was due to the direct toxic effects of large amounts of dietary raw egg white powder and not to biotin deficiency.
\end{abstract}

The objective of this investigation was to determine the clinical and pathological effects of increasing amounts of spray-dried raw egg white powder in the diet of young albino rats. The egg white powder used was similar to that incorporated into standard diets for the production of biotin deficiency syndromes in weanling albino rats, for example by Rubin, Drekter \& Moyer (1945).

In recent studies published from this laboratory, young adult albino rats were fed on the biotin-deficient diet of Rubin et al. (1945) and given a challenging daily oral dose of benzylpenicillin (Boyd \& Sargeant, I962) or caffeine (Peters \& Boyd, I966). A fulminating reaction appeared and most of the animals died within a week. Subcutaneous biotin supplementation had little or no effect upon the lethal reaction, which appeared to be due to some factor or factors in the synthetic diet other than biotin deficiency. A feature of the biotin-deficient diet is that it contains $30 \%$ of dried raw egg white powder; it appeared possible that the fulminating reaction was related to the toxic effects of raw egg white rather than to biotin deficiency.

A review of the early literature on biotin deficiency disclosed that most authors, such as György (1939), Bell, Davidson \& Scarborough (1953) and White, Handler \& Smith (I964), credit Bateman (I9I6) as having discovered this syndrome. On checking Bateman's (I9I6) report, it was found that he used 'large, healthy, white rats' and gave them a diet containing from 20 to $80 \%$ of raw egg white mixed with milk powder, bread meal and lard in unspecified amounts. The animals quickly developed anorexia, diarrhoea and loss of body-weight from the larger amounts of raw egg white, 
with some tolerance appearing after 7-10 days. Tscherkes (1927) and Maignon \& Chahine (I93I) used a diet containing $100 \%$ raw egg white and produced deaths within $3^{-5}$ days.

Boyd, Peters \& Krijnen (1966) calculated that young adult male rats would eat some $30-5 \circ \mathrm{g}$ of egg white powder per $\mathrm{kg}$ body-weight per day to obtain a calorie intake equivalent to that from Purina laboratory chow (Ralston Purina Company Limited, Woodstock, Ontario, Canada). They then found that a dose of $101 \pm 6 \mathrm{~g} / \mathrm{kg}$ of spraydried raw egg white powder, reconstituted with water and given intragastrically to young adult male rats on an empty stomach, killed $50 \%$ of the animals within $3^{-6} \mathrm{~h}$.

It is apparent, therefore, that toxicity due directly to raw egg white must be clearly differentiated from the biotin deficiency syndrome produced by feeding raw egg white powder. Boas (1927) was able to produce a biotin deficiency because she happened to select $30 \%$ raw egg white in the diet. As will be shown below, and as found originally by György (1939), adult rats tolerate this level of dietary egg white reasonably well but, as originally recorded by Boas (1927), weanling rats develop biotin deficiency. The distinction appears to have been originally appreciated, at least in part, by Parsons (193I) when she distinguished an 'early nutritive disaster' and a later vitamin deficiency syndrome in weanling rats receiving a diet containing $66 \%$ raw egg white.

\section{EXPERIMENTAL}

Expt $\mathrm{I}$. Female albino rats of a Wistar strain were used. They had been bred in this department and raised on Purina laboratory chow. The numbers of animals, their body-weights and the composition of the diets are given in Table $\mathbf{I}$.

The rats were housed separately in metabolism cages and transferred daily to clean cages. The diet was offered in a non-spilling feeding device. Body-weight, food and water intake and urine output were measured daily. The $\mathrm{pH}$ of urine and its protein and glucose contents were determined with Ames Combistix (Ames Company of Canada, Limited, Toronto, Ontario, Canada).

Daily clinical measurements were made for $\mathrm{I}_{4}$ days. The animals were then killed with chloroform, and the weight and water content of the organs listed in Table 4 were determined. Contents of the lumen of the gastro-intestinal tract were removed by a standardized washing and milking technique before weighing. The sample of muscle was the left half of the muscle layer of the ventral abdominal wall. The organs were dried to constant weight in a Fisher forced-draft constant temperature (isotemp) oven at $96^{\circ}$. Suitable portions of skin and of homogenized carcass were taken for water analysis.

Expt 2. Forty young male rats of $104 \pm \mathrm{I} 4 \mathrm{~g}$ (mean $\pm \mathrm{SD}$ ) body-weight were divided into five groups and fed on the same diets as the females in Expt $\mathrm{I}$ for 2 weeks; thirty-four other males of $108 \pm 15 \mathrm{~g}$ body-weight were fed for 4 weeks as shown in Table 2. Daily clinical measurements were omitted since they are included in Expt 3 . At the end of each experiment, the animals were killed with chloroform, the carcasses were treated as described for Expt I and the results compared with those obtained for females in Expt $\mathbf{x}$. 
Table I Expt I. Number and body-weight of rats and composition of diets

\begin{tabular}{|c|c|c|c|c|c|c|}
\hline \multirow[b]{2}{*}{ Group no. } & \multirow[b]{2}{*}{ No. of rats } & \multirow[b]{2}{*}{$\begin{array}{c}\text { Initial } \\
\text { body-weight } \\
\text { (mean } \pm \text { SD) } \\
\text { (g) }\end{array}$} & \multicolumn{4}{|c|}{ Diet* } \\
\hline & & & $\begin{array}{l}\text { Raw egg } \\
\text { white } \\
\text { powdert } \\
(\%)\end{array}$ & $\begin{array}{c}\text { Maize } \\
\text { starch } \\
(\%)\end{array}$ & $\begin{array}{c}\text { Cottonseed } \\
\text { oil } \\
(\%)\end{array}$ & $\begin{array}{c}\text { Salt } \\
\text { mixturet } \\
(\%)\end{array}$ \\
\hline $\mathbf{I}$ & 9 & $144 \pm 14$ & 20 & 70 & 5 & 5 \\
\hline 2 & I I & I39 \pm I 5 & 40 & 50 & 5 & 5 \\
\hline 3 & I I & $142 \pm 15$ & 60 & 30 & 5 & 5 \\
\hline 4 & II & $140 \pm$ I I & 80 & 10 & 5 & 5 \\
\hline 5 & 12 & $145 \pm 9$ & $100 \S$ & - & - & - \\
\hline 6 & 7 & $150 \pm 10$ & \multicolumn{4}{|c|}{ Pulverized Purina laboratory chow } \\
\hline
\end{tabular}

* An all-vitamin supplement (General Biochemicals Inc., Chagrin Falls, Ohio) was added to the diets of groups $\mathrm{I}-\mathbf{5}$.

† Spray-dried taw egg white powder as used in biotin-deficient diets and obtained from General Biochemicals Inc., Chagrin Falls, Ohio. It contained not less than $80 \%$ protein, $8 \%$ water and $5.3 \%$ ash.

$\ddagger$ Phillips Hart IV (Rubin et al. 1945).

$\S$ Group 5 received orally in addition $200 \mathrm{mg}$ of a general vitamin supplement (Nutritional Biochemicals Corporation, Cleveland, Ohio) daily.

Table 2. Expt 2. Growth of young male albino rats fed on chow and diets containing different levels of egg white powder for 2 and 4 weeks

\begin{tabular}{|c|c|c|c|c|}
\hline \multirow{2}{*}{$\begin{array}{l}\% \text { raw } \\
\text { egg white } \\
\text { powder }\end{array}$} & \multicolumn{2}{|c|}{2 weeks feeding } & \multicolumn{2}{|c|}{4 wceks feeding } \\
\hline & $\begin{array}{l}\text { No. of } \\
\text { animals }\end{array}$ & $\begin{array}{c}\text { Body-weight } \\
\text { gaint }\end{array}$ & $\begin{array}{l}\text { No. of } \\
\text { animals }\end{array}$ & $\begin{array}{c}\text { Body-weight } \\
\text { gain } \dagger\end{array}$ \\
\hline 20 & 8 & $61 \pm 9$ & 7 & III $1 \mathrm{I} 7^{*}$ \\
\hline 40 & 8 & $65 \pm 12 *$ & 7 & $108 \pm 14$ \\
\hline 60 & 8 & $65 \pm 23$ & 7 & $108 \pm 33$ \\
\hline 80 & 8 & $3^{6} \pm \mathrm{I} 2 *$ & 7 & $83 \pm 32$ \\
\hline o (chow) & 8 & $51 \pm 13$ & 6 & $96 \pm 7$ \\
\hline
\end{tabular}

$\dagger$ Expressed as percentage gain (mean $\pm \mathrm{sD}$ ) from initial body-weight. Means that differed at $P=0 \cdot 05^{-}$ 0.02 from corresponding means for controls fed on laboratory chow are indicated by an asterisk.

\section{Table 3. Expt 3. A summary of clinical measurements made upon the rats*}

\begin{tabular}{|c|c|c|c|c|c|}
\hline $\begin{array}{c}\text { Diet } \\
\text { (no. of diet) }\end{array}$ & $\begin{array}{l}\text { No. of } \\
\text { animals }\end{array}$ & $\begin{array}{l}\text { Daily } \\
\text { gain in } \\
\text { body-weight } \\
\text { (mean } \pm S D) \\
\text { (g) }\end{array}$ & $\begin{array}{c}\text { Daily } \\
\text { food } \\
\text { intake } \\
(\text { mean } \pm \mathrm{SD}) \\
(\mathrm{g})\end{array}$ & $\begin{array}{c}\text { Daily } \\
\text { water } \\
\text { intake } \\
(\text { mean } \pm \mathrm{sD}) \\
(\mathrm{ml})\end{array}$ & $\begin{array}{c}\text { Daily } \\
\text { urinary } \\
\text { volume } \\
\text { (mean } \pm \mathrm{SD}) \\
(\mathrm{ml})\end{array}$ \\
\hline $\begin{array}{l}\text { egg white } \\
\text { (I) }\end{array}$ & 9 & $3.9 \pm 0.8$ & $12 \pm I$ & $37 \pm 7$ & $26 \pm 4$ \\
\hline $\begin{array}{l}\text { egg white powder } \\
\text { tin supplement (2) }\end{array}$ & 9 & $4 \cdot 2 \pm I \cdot 2$ & $r 3 \pm r$ & $39 \pm 6$ & $26 \pm 4$ \\
\hline $\begin{array}{l}\text { atured egg } \\
\text { owder (3) }\end{array}$ & 10 & $5 \cdot 7 \pm \mathbf{I} 0$ & 一 & $44 \pm 5$ & - \\
\hline $\begin{array}{l}\text { sein }(4) \\
\text { tory chow (5) }\end{array}$ & $\begin{array}{r}10 \\
9\end{array}$ & $\begin{array}{l}6 \cdot 0 \pm 1 \cdot 4 \\
5 \cdot 8 \pm 0 \cdot 7\end{array}$ & $\begin{array}{l}I 4 \pm I \\
I 4 \pm I\end{array}$ & $\begin{array}{l}39 \pm 5 \\
23 \pm I\end{array}$ & $\begin{array}{r}25 \pm 3 \\
3 \pm 1\end{array}$ \\
\hline
\end{tabular}

- Clinical measurements are expressed as the mean \pm SD of daily mean values during the 14 days of the experiment. The food intake of animals fed on laboratory chow was calculated as calorie-equivalent to that of animals given the high-protein diet (i.e. the $g$ intake of laboratory chow was $r \cdot 3$ times the figures listed above). Animals fed denatured egg white spilled their food and this made accurate readings of food intake and urinary volume impossible. 
Expt 3. Forty-seven young male rats weighing $\mathrm{I} 33 \pm \mathrm{II} g$ were divided in five groups for measurement of the effect of biotin supplementation, heat denaturation of egg white, and of corresponding high intake of another protein, casein, as shown in Table 3. The high-protein diets were the same as that received by group 4 in Table $\mathrm{I}$, except for changes in the protein fraction as indicated in Table 3. Animals in the group 2 were given $100 \mu \mathrm{g}$ biotin subcutaneously every 2 nd day. The egg white diet of group 3 was denatured by autoclaving with steam and pressure for $\mathrm{I} h$. The casein of diet 4 was Vitamin Free Test Casein (General Biochemicals Incorporated, Chagrin Falls, Ohio). All diets contained vitamin supplements as shown in Table I.

The animals were treated as in Expt I for 14 days except that the urine was not analysed and the urinary volume was not measured for group 5 . The animals were killed after I4 days and the same measurements made as in Expt I; in addition, the weights of the contents of the stomach, small bowel, caecum and colon were recorded.

\section{RESULTS}

Expt I

Clinical observations. Clinical signs of toxicity increased with increasing amounts of raw egg white powder in the diet fed to female rats for a period of 2 weeks. The most sensitive measurement was urinary volume which was significantly increased by some $50 \%$ in rats receiving $20 \%$ egg white and rose to sixfold when egg white powder reached $80 \%$. Urinary protein output, expressed as $\mathrm{mg} / \mathrm{kg}$ body-weight per day, increased with increase in the diuresis. Urinary $\mathrm{pH}$, reaching 9 in all rats receiving egg white, was significantly higher than the $\mathrm{pH}$ of 6.8 observed in the controls fed on laboratory chow.

The diuresis was accompanied by an increase in water intake as shown in Fig. I for results collected on the $I_{5}$ th and IIth days of feeding. These days were selected because on them the food intake, which influences water consumption (Strominger, 1946-7), was almost equal in the several groups.

Food intake was not significantly lowered until raw egg white powder reached $80 \%$ of the diet. At this point growth was significantly inhibited. Rats fed on $100 \%$ egg white exhibited marked anorexia and loss of body-weight.

Soft stools appeared in animals receiving diets containing 60 and $80 \%$ raw egg white powder and at $100 \%$ there was a frank diarrhoea. The latter animals had glycosuria and one of the twelve rats died.

Autopsy observations. As the proportion of egg white was increased in the diet, there occurred a progressive decline in carcass weight compared with that in controls fed on laboratory chow. There was loss of absolute wet weight in all organs except brain, cardiac stomach, kidneys and submaxillary salivary glands. At $20 \%$ dietary egg white there were significant losses in wet weight of caecum, colon and liver. As the proportion of dietary egg white increased there appeared resistance to further loss of weight in the alimentary organs and at $100 \%$ egg white the absolute weight of caecum and salivary glands had actually increased. In the latter animals there was marked loss of weight in most other organs, particularly in the ovaries and thymus gland. 
Significant dehydration was recorded in all organs except cardiac stomach, kidneys, skin and thymus gland from feeding one or more proportions of egg white. Dehydration of the brain did not appear until the proportion reached $100 \%$. When all results

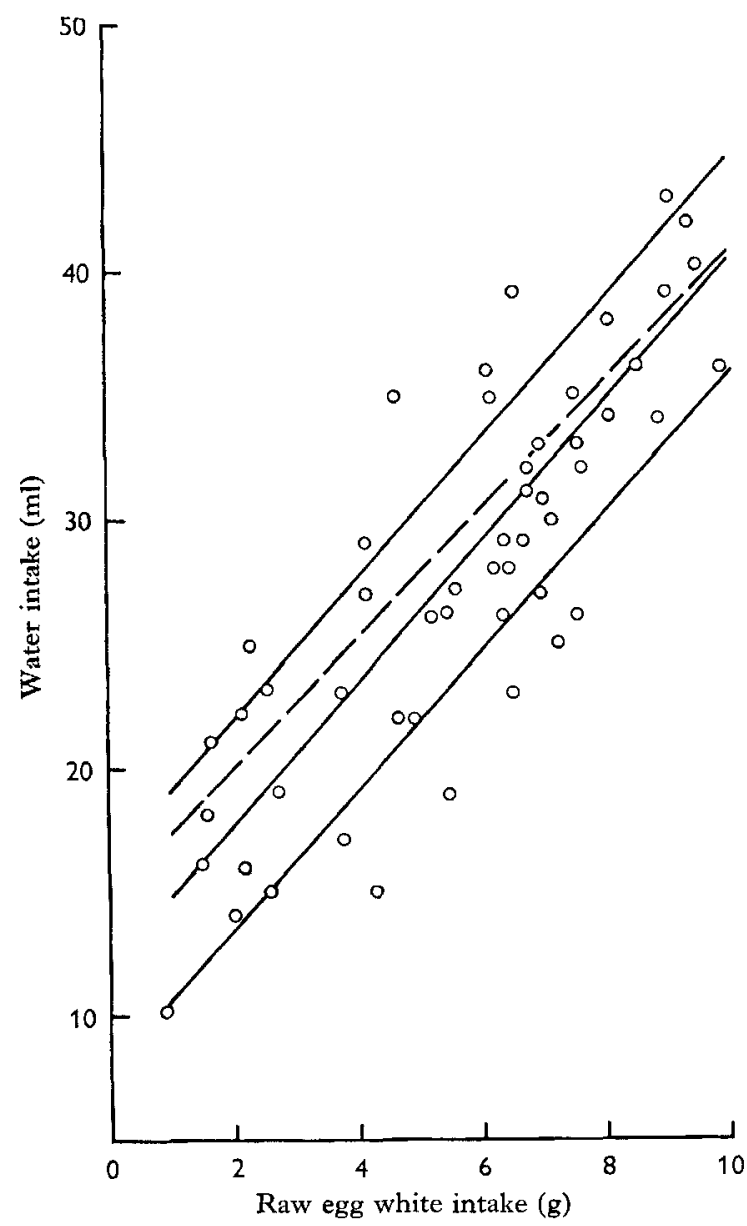

Fig. I. The regression of water intake on intake of raw egg white powder during the 5 th day of feeding. The regression line is shown as the middle solid line, plus its standard error as the upper solid line, and minus its standard error as the lower solid line, as calculated from the equation, $Y=(12 \cdot 0+2 \cdot 8 X) \pm 4 \cdot 2(r=+0.85)$. The results of the $\mathrm{I} I$ th day of feeding are indicated by a regression (interrupted) line only.

were averaged, there was found to be significant dehydration of skin and thymus gland. Dehydration appeared in animals receiving $20 \%$ raw egg white, and higher dietary proportions did not apppreciably augment the dehydration. Loss of wet weight, therefore, was due in part to loss of tissue water (see Table 4 ).

\section{Expt 2}

Increasing percentages of dietary raw egg white powder inhibited growth somewhat less in males than in females, as shown in Table 2. The relationship of organ weight, expressed as a percentage of carcass weight in autopsies at 14 and 28 days, to increasing 
proportions of dietary egg white is illustrated in Fig. 2. Loss of absolute organ weight was less extensive in males than in females. The absolute weight of some organs was increased; for example that of salivary glands and kidneys in male rats receiving $80 \%$ raw egg white powder. The organs of males were less dehydrated than were the organs of females.

Table 4. Changes in organ water content in female rats fed on diets containing raw egg white powder for 2 weeks

\begin{tabular}{|c|c|c|c|c|c|}
\hline \multirow[b]{2}{*}{ Organ } & \multicolumn{5}{|c|}{$\%$ Raw egg whitef } \\
\hline & 20 & 40 & 60 & 80 & 100 \\
\hline Adrenal glands & $-\mathrm{I} \cdot 38$ & $-3 \cdot 45^{*}$ & $-2 \cdot 26^{*}$ & $-2 \cdot 67^{*}$ & $-2 \cdot 19$ \\
\hline Brain & +0.07 & +0.04 & -o.or & +0.14 & $-0.42^{*}$ \\
\hline \multicolumn{6}{|l|}{ Gastro-intestinal tract } \\
\hline Cardiac stomach & $+1 \cdot 04$ & $-0.4 I$ & -0.83 & +0.01 & +0.38 \\
\hline Pyloric stomach & -0.05 & $-1 \cdot 37^{*}$ & -1.02 & -0.45 & +0.18 \\
\hline Small bowel & $-1 \cdot 26 * *$ & $-0.93^{*}$ & -0.76 & $-\mathrm{I} \cdot 14^{*}$ & +0.41 \\
\hline Caecum & $-I \cdot 55$ & $-1 \cdot 63 *$ & $-1 \cdot 13$ & -0.55 & +0.17 \\
\hline Colon & $-2 \cdot 47^{* *}$ & $-2 \cdot 78^{* *}$ & $-2 \cdot 29 * *$ & $-2 \cdot 53 * *$ & $-I \cdot 28 * *$ \\
\hline Heart & -0.27 & -0.60 & $-0.6 \mathrm{I}$ & $-0.73^{*}$ & -0.47 \\
\hline Kidneys & +0.86 & +0.49 & $+2 \cdot 60$ & +0.19 & +0.12 \\
\hline Liver & +0.53 & -0.65 & $-I \cdot x 6^{* *}$ & $-I \cdot I 6$ & -0.57 \\
\hline Lungs & $-0.69^{*}$ & $-0.66^{*}$ & $-0.6 I *$ & -0.79 & $-0.89 * *$ \\
\hline Muscle (ventral abdominal wall) & -0.71 & $-1 \cdot 14^{*}$ & $-0.9 I * *$ & -0.56 & +0.12 \\
\hline Ovaties & $-1 \cdot 07$ & $-2.07^{*}$ & $-1 \cdot 52$ & $-2 \cdot 56 * *$ & $-2 \cdot 44^{*}$ \\
\hline Skin & $-3 \cdot 38$ & $-3 \cdot 93$ & $-3 \cdot 64$ & $-3 \cdot 36$ & $+0.3^{8}$ \\
\hline Spleen & -0.30 & $-0.84 * *$ & $-0.77^{* *}$ & $-0.77^{* *}$ & $-I \cdot 25 * *$ \\
\hline Submaxillary salivary glands & $-\mathrm{I} \cdot 57$ & -0.91 & $-0.6 \mathrm{I}$ & $-1 \cdot 53^{*}$ & $-2 \cdot 04 *$ \\
\hline Thymus & -0.27 & $-I \cdot 34$ & -0.89 & -0.67 & -0.03 \\
\hline Residual carcass & $-I \cdot 73^{*}$ & $-I \cdot 55$ & $-2 \cdot 58 *$ & $-\mathrm{I} \cdot 48$ & -0.98 \\
\hline
\end{tabular}

+ Changes in rats fed on raw egg white powder are expressed as mean percentage change from the animals fed on chow. Means that differed at $P=0.05^{-0.02}$ from corresponding means for rats fed on chow are indicated by one asterisk and at $P \leqq 0.0$ I by two asterisks.

\section{Expt 3}

The clinical measurements are summarized in Table 3. All diets containing $80 \%$ protein produced a marked diuresis. Water intake was increased by an amount approximately equal to the increase in urinary volume. The calorie intake was the same in all groups. Growth rate, however, was significantly lower in rats receiving raw egg white powder, with or without biotin supplementation, than in rats receiving denatured egg white, casein, or laboratory chow.

Weights at autopsy are summarized in Table 5 . Compared with laboratory chow, the diet of $80 \%$ casein produced a loss of absolute weight in the tissues and luminal contents of the caecum and colon and a gain in absolute weight of kidneys and liver. The absolute weights of organs in rats receiving denatured egg white differed in some instances from those in rats receiving casein as noted in Table 5. In rats receiving raw egg white powder, with or without biotin supplements, there was loss of absolute weight in all organs except brain and salivary glands; caecum and colon weighed more than in rats fed on casein but less than in rats fed on laboratory chow. There were other lesser differences as noted in Table 5 . 
Compared with laboratory chow, $80 \%$ casein produced a dehydration of many organs which was significant in caecum, colon, muscle, spleen and salivary glands. All three egg white diets had similar effects, which consisted essentially in elimination of most of the dehydration produced by casein.

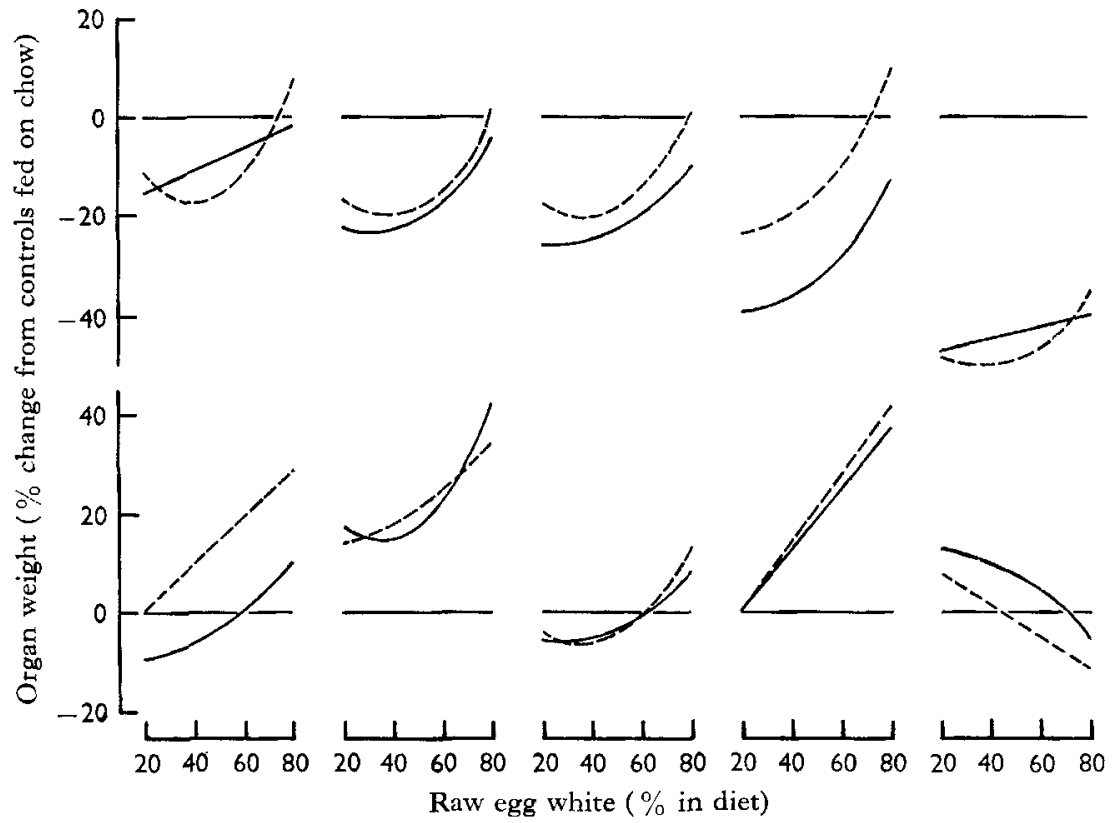

Fig 2. Relationships between organ weights and level of dietary raw egg white powder in young male rats after 2 weeks (solid lines) and 4 weeks (interrupted lines) of feeding. Organ weights were calculated as percentage of body-weight at autopsy and expressed as percentage change from the mean of controls fed on laboratory chow. The correlation coefficients, in parentheses for the regression after 2 and 4 weeks of feeding were as follows: upper row from left to right: cardiac stomach $\left(+0.55^{* *} ; 0.5^{* *}\right)$, pyloric stomach $\left(0.76^{* *} ; 0.70^{* *}\right)$, small bowel $\left(0.64^{* *} ; 0.83^{* *}\right)$, caecum $\left(0.72^{* *} ; 0.60^{* *}\right)$, colon $\left(+0.42 ; 0.69^{* *}\right)$; bottom row from left to right: adrenal glands $\left(0.5 \mathrm{I}^{* * *} ;+0.65^{* *}\right)$, submaxillary salivary glands $\left(0.74^{* *} ; 0.49^{* *}\right)$, brain $\left(0.48^{* *} ; 0.63^{* *}\right)$, kidneys $\left(+0.88^{* *} ;+0.89^{* *}\right)$, and skin $\left(0.42^{* *} ;-0.83^{* *}\right)$. Coefficients which differed at $P=0.05^{-0.02}$ are indicated by one asterisk and at $P \leqq 0.01$ by two asterisks. The sign of the correlation coefficient is not indicated when the best-fitting equation was parabolic.

\section{DISCUSSION}

The results of this study showed that inclusion of as little as $20 \%$ raw egg white powder, but particularly of $80 \%$ or more, in the diet produced measurable signs of acute toxicity in adult female and young male rats.

Bateman's ( 1916$)$ original description of reduced food intake, weight loss, some development of tolerance after 7 -10 days, soft stool and diarrhoea was confirmed in the present study and extended to include other clinical and pathological measurements. The resuits indicate that the toxicity syndrome originally reported by Bateman (1916) was not due to biotin deficiency, but to the direct toxicity of raw egg white powder. When adult rats received $80 \%$ or more in their diet, it produced an acute toxicity syndrome and sometimes death. The toxic effects were not lessened by a 
biotin supplement, but were significantly decreased by heat denaturation of the raw egg white powder. Diets containing $80 \%$ of the denatured egg white were no more toxic than diets containing $80 \%$ casein which were well tolerated, judged by the criteria used, although changes occurred, for example in certain organ weights and water levels.

Table 5. Expt 3. Weights of organs and gastro-intestinal contents of young male rats fed on diets containing different proteins for 2 weeks

\begin{tabular}{|c|c|c|c|c|c|}
\hline \multirow[b]{2}{*}{ Organ } & \multirow[b]{2}{*}{$\begin{array}{l}80 \% \text { casein, } \\
\text { mean \% of net } \\
\text { body-weight at } \\
\text { autopsy } \pm \mathrm{SD}\end{array}$} & \multicolumn{4}{|c|}{ Weight $\uparrow$ of organs on diet with: } \\
\hline & & $\begin{array}{l}80 \% \text { raw } \\
\text { egg white } \\
\text { powder }\end{array}$ & $\begin{array}{l}80 \% \text { raw } \\
\text { egg white } \\
\text { powder plus } \\
\text { biotin }\end{array}$ & $\begin{array}{c}80 \% \\
\text { denatured } \\
\text { egg white } \\
\text { powder }\end{array}$ & $\begin{array}{c}\text { Laboratory } \\
\text { chow }\end{array}$ \\
\hline Adrenal glands & $0.0203 \pm 0.0017$ & $+7 \cdot 9^{*}$ & $+8 \cdot 7^{* *}$ & $+14 \cdot 2 * *$ & $-6 \cdot 8$ \\
\hline Brain & $0.860 \pm 0.060$ & $+r_{4} \cdot 2^{* *}$ & $+1 x \cdot 5 * *$ & $+3 \cdot 8$ & $+3 \cdot 0$ \\
\hline \multicolumn{6}{|l|}{ Gastro-intestinal tract } \\
\hline Cardiac stomach & $0.146 \pm 0.0 I_{4}$ & $+7 \cdot 4$ & -6.8 & $-9 \cdot 0^{*}$ & $+2 \cdot 9$ \\
\hline Pyloric stomach & $0.410 \pm 0.034$ & 0.0 & $-5 \cdot 2$ & $-12 \cdot 3^{* *}$ & $-6 \cdot 0$ \\
\hline Small bowel & $I \cdot 289 \pm 0.092$ & $+9 \cdot 7^{*}$ & $+I_{5} \cdot 0^{* * *}$ & $+17 \cdot 6 * *$ & $-2 \cdot 0$ \\
\hline Caecum & $0.284 \pm 0.05 \mathrm{I}$ & $+32 \cdot 7^{* *}$ & $+38 \cdot 9^{* * *}$ & $+28 \cdot 7^{* *}$ & $+8 \mathrm{I} \cdot 4^{* *}$ \\
\hline Colon & $0.35^{8} \pm 0.03 \mathrm{I}$ & $+14 * 1 *$ & $+9 \cdot 1$ & $+19 \cdot 6 * *$ & $+67 \cdot 5 * *$ \\
\hline Heart & $0.401 \pm 0.025$ & $-2 \cdot 8$ & -0.7 & $-4 \cdot 6$ & $-3 \cdot 2$ \\
\hline Kidneys & $I \cdot 408 \pm 0.094$ & $-2 \cdot 9$ & $+2 \cdot 4$ & $+\mathrm{I} \cdot 8$ & $-2 I \cdot 9^{* *}$ \\
\hline Liver & $6.751 \pm 0.628$ & $-8 \cdot 7$ & $-6 \cdot 2$ & $-7 \cdot 9$ & $-12.9^{* *}$ \\
\hline Lungs & $0.506 \pm 0.020$ & $+5 \cdot 5$ & $+17 \cdot 4$ & $+4 \cdot 6$ & $+1 \cdot 5$ \\
\hline $\begin{array}{l}\text { Muscle (ventral } \\
\text { abdominal wall) }\end{array}$ & $1.632 \pm 0.110$ & $+1 \cdot 3$ & -0.8 & $+3 \cdot 4$ & $+I \cdot 4$ \\
\hline Skin & $22.98 \pm 0.88$ & $-7 \cdot 2 * *$ & $-7 \cdot 1 * *$ & $-6 \cdot 2^{* *}$ & $+3 \cdot 4$ \\
\hline Spleen & $0.318 \pm 0.036$ & +0.9 & $+2 \cdot 4$ & $+1 \cdot 3$ & $+I 0 \cdot \mathrm{I}$ \\
\hline $\begin{array}{l}\text { Submaxillary salivary } \\
\text { glands }\end{array}$ & $0.192 \pm 0.019$ & $+38 \cdot 1 * *$ & $+47 \cdot 1 * *$ & $+14.4 *$ & $+6 \cdot 2$ \\
\hline Testes & $I \cdot 28$ I \pm 0.1 I I & $+12 \cdot 5$ & $+7 \cdot 2$ & -0.8 & -0.7 \\
\hline Thymus gland & $0.266 \pm 0.040$ & $-2 \cdot 6$ & -10.5 & - II $\cdot 0$ & $+7 \cdot 8$ \\
\hline Residual carcass & $51 \cdot 72 \pm 1 \cdot 17$ & $+3 \cdot 1 * *$ & $+1 \cdot 8$ & $+2 \cdot 7^{* *}$ & +0.1 \\
\hline $\begin{array}{l}\text { Net body-weight } \\
\text { at autopsy }\end{array}$ & $202 \pm 18$ & $-14 \cdot 3^{* * *}$ & $-12 \cdot 3^{* *}$ & $-4 \cdot 3$ & $-4 \cdot 4$ \\
\hline \multicolumn{6}{|l|}{ Contents of } \\
\hline Stomach & $3 \cdot 7 \pm 1 \cdot 7$ & $-32 \cdot 9$ & $-37 \cdot 8$ & $-64 \cdot 0 * *$ & $+33 \cdot 9$ \\
\hline Small bowel & $6 \cdot 3 \pm 1 \cdot 0$ & $-25 \cdot 8 * *$ & $-20.0 * *$ & $+17 \cdot 0^{*}$ & $+18 \cdot 4^{*}$ \\
\hline Caecum & $2 \cdot 2 \pm 0.5$ & $+57.0 * *$ & $+76 \cdot 0^{* * *}$ & $+75^{\circ} 0^{* * *}$ & $+154.9^{* * *}$ \\
\hline Colon & $I .1 \pm 0.3$ & -13.0 & $-5 \cdot 9$ & $+63 \cdot 0^{* *}$ & $+10_{3} \cdot 8 * *$ \\
\hline
\end{tabular}

$\uparrow$ Results are expressed as mean percentage change from animals fed on $80 \%$ casein. Means that differed at $P=0.05^{-0.02}$ from corresponding means of animals fed on casein are indicated by one asterisk and at $P \leqq 0 \cdot 0$ I by two asterisks.

$\ddagger$ Net body-weight at autopsy is body-weight at autopsy minus the total weight of gastro-intestinal contents. Net body-weight at autopsy and weight of intestinal contents for rats fed on casein are expressed as mean values $(\mathrm{g}) \pm \mathrm{sD}$.

It may be calculated that animals given diets containing $80 \%$ or $100 \%$ raw egg white powder ate some $40-50 \mathrm{~g} / \mathrm{kg}$ body-weight of this powder per day. The daily consumption was, therefore, about one-half the oral lethal dose of raw egg white powder found by Boyd et al. (r966). It might be expected that some of the signs of acute toxicity would be produced by these amounts of raw egg white powder. The following signs were common to both experiments: diarrhoea, anorexia, loss of 
body-weight, polydipsia, diuresis, proteinuria, alkalinuria, dehydration of body organs and death.

Finally, it is apparent that the results of this study can explain the augmented susceptibility of adult albino rats to the toxic effects of benzylpenicillin, reported by Boyd \& Sargeant (I962), and of caffeine reported by Peters \& Boyd (I966), when the food of rats was changed from laboratory chow to the raw egg white, biotin-deficient diet. The fulminating lethal reactions which followed change of diet could have been due to a combination of the sublethal toxic effects of raw egg white and of benzylpenicillin or caffeine, sufficient to kill the animals.

The author was a Fellow of the Medical Research Council of Canada. The project was undertaken under a grant-in-aid of the Medical Research Council of Canada. The author wishes to thank Professor Eldon M. Boyd for professional advice and assistance, Miss C. J. Krijnen for technical assistance and Mr D. Card for statistical analysis.

\section{REFEREN CES}

Bateman, W. G. (19r6). \%. biol. Chem. 26, 263.

Bell, G. H., Davidson, J. N. \& Scarborough, H. (1953). Textbook of Physiology and Biochemistry, 2nd ed. p. Ior. Edinburgh: E. and S. Livingstone.

Boas, M. A. (1927). Biochem. F. 21, 712.

Boyd, E. M., Peters, J. M. \& Krijnen, C. J. (1966). Ind. Med. Surg. 35, 782.

Boyd, E. M. \& Sargeant, E. J. (r962). F. New Drugs 2, 283.

György, P. (1939). F. biol. Chem. 13x, 733 .

Maignon, F. \& Chahine, M. A. (I93 I). C. r. Séanc. Soc. Biol. ro8, 868.

Parsons, H. T. (1931). 7. biol. Chem. 90, 35 r.

Peters, J. M. \& Boyd, E. M. (1966). Toxic. appl. Pharmac. 8, 350.

Rubin, S. H., Drekter, L. \& Moyer, E. H. (1945). Proc. Soc. exp. Biol. Med. 58, 352.

Strominger, J. L. (1946-7). Yale F. Biol. Med. 19, 279.

Tscherkes, L. A. ( 1927). Boichem. Z. 182, 35.

White, A., Handler, P. \& Smith, E. L. (1964). Principles of Biochemistry, 3rd ed., p. 962. Toronto: McGraw-Hill. 